ISSN 2078-6441. Вісник Львівського університету. Серія географічна. 2013. Випуск 42. С. 160-169. Visnyk of the Lviv University. Series Geography. 2013. Issue 42. P. 160-169.

911.3:32 (477.83/.86)

(1772-1918)

\author{
ом н обзяк \\ ьвівський н ціон льний університет імені в н \\ вул. . орошенк , 41, 79000, м. ьвів, кр їн
}

ро н лізов но зміни дміністр тивно-територі льного поділу личини впродовж кінця XVIII-поч тку ст. озроблено схему послідовності дміністр тивних одиниць території кр ю. пропонов но періодиз цію політико- дміністр тивного поділу личини в встрійський період. од но дві оригін льні к ртогр фічні моделі.

лючові слов : дміністр тивно-територі льний поділ, циркул, дистрикт, повітове ст роство, под тково-судовий повіт, дміністр тивний повіт, личин .

дміністр тивно-територі льний поділ відобр ж є вплив держ вних орг нів вл ди н підпорядков ну їй територію, відповідно до якого формується мереж дміністр тивних одиниць різного рівня. олітико- дміністр тивний поділ личини в встрійський період уперше н був форм уніфіков ності, чіткої підпорядков ності і систем тичності. ому його дослідження є кту льним з н укового т пр ктичного погляду.

роблем тикою дміністр тивно-територі льного устрою личини в встрійський період 3 йм ються перев жно історики т н уковці негеогр фічних г лузей. еред дослідників цієї тем тики н звемо . p к, який н підст ві к ртогр фічних м тері лів відстежив зміни в дміністр тивно-територі льному поділі кр ю $[3,4] . \quad$ кож цік вими є дослідження історик . ерменич, пов'яз ні з еволюцією політичного устрою в окремих регіон х кр їни [1].

дним з перших геогр фів, хто про н лізув в дміністр тивний поділ території кр їни протягом історичного ч су, ст в . ністрянський [2]. р ця . обзяк присвячен к ртогр фічному моделюв нню дміністр тивно-територі льного устрою греко-к толицької церкви в личині в першій половині ст. [6]. дн к пр ць, у яких висвітлюв ли б геогр фію політико- дміністр тивного поділу з встрійського п нув ння, в укр їнській н уковій літер турі, н н шу думку, є недост тньо.

ш мет - вивчення послідовності змін дміністр тивно-територі льних одиниць личини в встрійський період, розробк періодиз ції політико- дміністр тивного поділу кр ю того ч су.

1772 р. ч стину укр їнських земель, що входили до скл ду ечі осполитої, приєдн но до встрійської ( бсбурзької) мон рхії як провінцію під н звою “ оролівство личини т олодимирії”. дміністр тивно в меж х колишньої ечі осполитої ці землі з йм ли ервоногородський повіт одільського воєводств, яноцьку, еремиську, ьвівську, лицьку і кр йню південну смугу олмської земель уського воєводств, елзьке воєводство, з хідні ч стини ременецького і уцького повітів олинського воєводств, ільзненський і південну ч стину ндомирського повітів

(C) обзяк ., 2013 
ндомирського воєводств , иржицький, нчиський і ичський повіти р ківського воєводств т князівств свенцімське і торське.

ціс рським п тентом від 15 серпня 1772 р. проведено дем рк цію кордонів нової провінції т розділено іiі н шість дміністр тивно-територі льних одиниць [7], які отрим ли н зву кр йс (від нім. Kreis - круг, коло) бо циркул (від л т. circulus). кий поділ н кр йси вже існув в н території встрійської мон рхії в меж х земель ехії т

горщини. офіційних документ х т к ртогр фічних м тері л х, вид них н території личини в цей період німецькою мовою, для озн чення нової дміністр тивної одиниці провінції вжив ли слово “Kreis”. укр їнській н уковій літер турі як відповідник новому дміністр тивно-територі льному утворенню з пропонов но н зву “округ” [2, 3], н томість у польській - ч сто тр пляється слово “циркул” [7, 9].

овий дміністр тивно-територі льний устрій уведено в дію в середині 1773 р. [6]. ентр ми округів ст ли міст ьвів, лич, мбір, мостя, яшів і елічк . ерші чотири були в меж х укр їнської етнічної території, м. яшів - н польсько-укр їнському погр ниччі, i лише одне ( елічк) предст вляло польську ч стину новоствореної провінції. зви деяких циркулів не збіг лися з н зв ми їніх дміністр тивних центрів: м. мостя було центром елзького округу, яшів - ільзненського.

иркули ділили н дистрикти (від нім. Kreisdistrikt - “окружн територія”) (див. рис. 1). польській літер турі вжив ли т кож слово “округ” (okręg) [7, 9]. ісля першого дміністр тивно-територі льного поділу в личині н лічув ли 60 дистриктів [7]. хніми центр ми ст в ли міст, містечк ін віть великі сел .

о скл ду ьвівського циркулу входило десять дистриктів: в , овкв , роди , роди , ородок, ібрк , олочів, борів, ереж ни, еребовля [7]. ериторія цього округу відповід л приблизно ьвівському i еребовлянському повіт м уського воєводств 3 невеликою прикордонною ч стиною елзького воєводств ( $\mathrm{B}) \mathrm{T}$ ч стиною ременецького i уцького повітів олинського воєводств . меж х лицького циркулу було утворено 13 дистриктів: ид чів, лич, он стириськ , уд нів, ортків, олин , исмениця, лум ч, двірн , елятин, нятин, торопи, осів. територією охоплення округ 3 йм в колишні ид чівський і лицький повіти уського воєводств т ервоногородський повіт одільського воєводств . мбірський циркул поділяли н дев'ять дистриктів 3 т кими центр ми: росл в, убецько, еремишль, янок, ісько, ісковичі, рогобич, трий і ще дв невідомі. удячи з геогр фії розміщення центрів, територія поширення цього округу збіг л ся з меж ми колишніх еремиської і яноцької земель уського воєводств , крім 3 хідної смуги. о елзького циркулу з центром у мості н леж ли вісім дистриктів: ор й, мостя, рубешів, лянів, щів, гнів, итків, юб чів, що цілковито відповід ло колишньому елзькому воєводству.

н чн кількість дистриктів споч тку бул необхідн для дет льного озн йомлення 3 цією територією т швидкого і достовірного збир ння інформ ції, що н с мперед цік вил нову вл ду. воступеневий дміністр тивно-територі льний устрій 3 великою кількістю дистриктів, не вл стивий тодішній встрійській мон рхії, проіснув в недовго. 1774 р. уряд зменшив кількість дистриктів до 19, з лишивши кількість циркулів без змін [7].

роект нового дміністр тивно-територі льного поділу був уведений в дію 1777 р. [3]. ідповідно до нього, ьвівський циркул розділено н дистрикти з центр ми у овкві, род х і ереж н х; лицький 3 центром у т нісл вові - н дистрикти з центр ми в личі, исмениці, оломиї і ліщик х; мбірський циркул охоплюв в дистрикти еремишль, ісько і рогобич; елзький округ з центром в мості розділе- 
но н дистрикти ілгор й, мостя і ок ль; ільзненський циркул з центром у яшеві охоплюв в дистрикти рнув, еж йськ і оросно; елицький - дистрикти з центр ми в торі, ишниці й овому ончі. г лом же територія округів м йже не змінил ся.

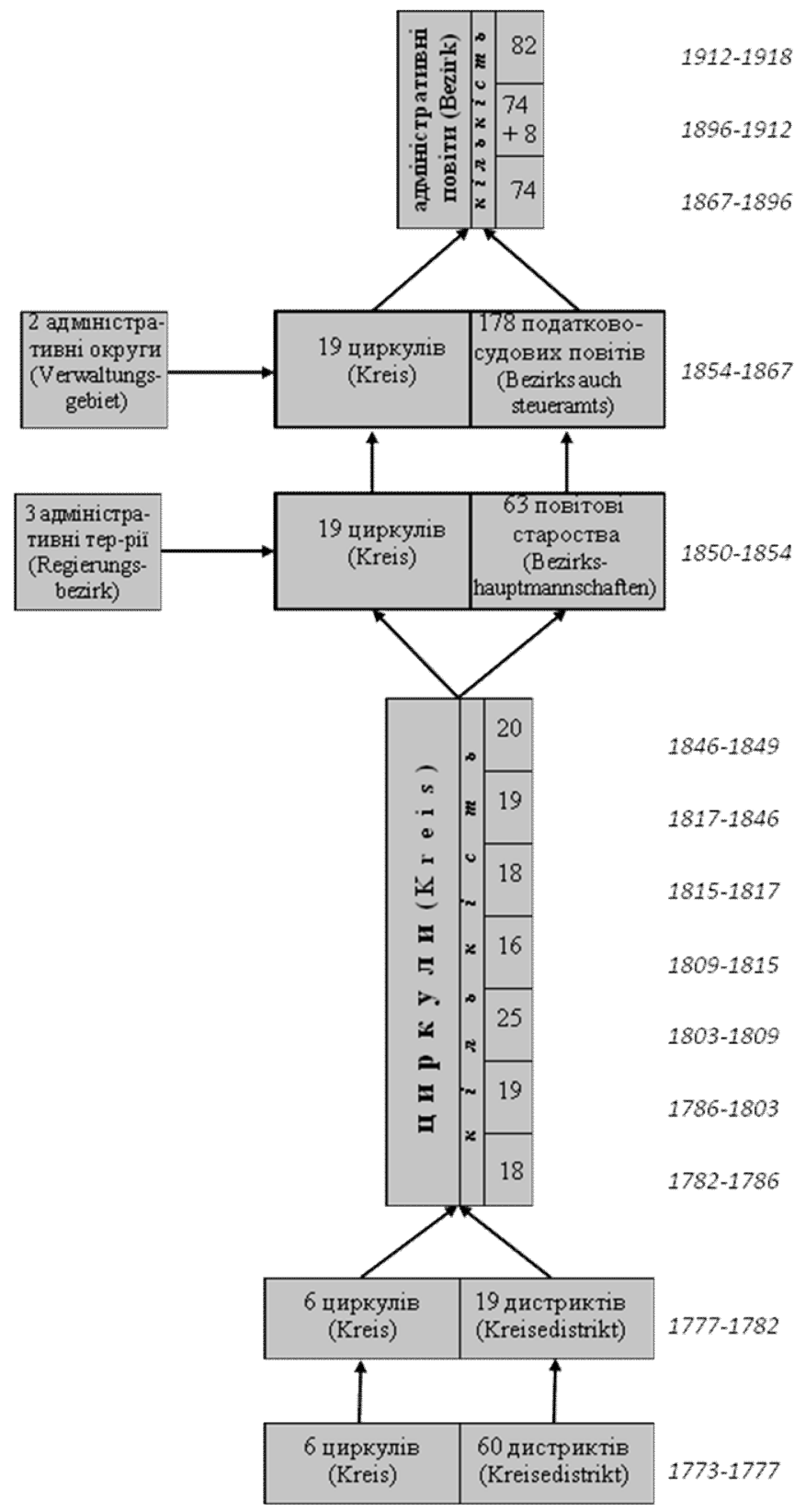

ис. 1. хем послідовності дміністр тивно-територі льного устрою личини в встрійський період. 
1782 р. встрійський уряд провів чергову дміністр тивну реформу, 3 якою 3 мість двоступеневого дміністр тивно-територі льного устрою введено одноступеневий (див. рис. 1). круги як великі територі льні одиниці ліквідов но, дистрикти, які н зив ли циркул ми, підпорядков но безпосередньо дміністр тивному центру провінції [3]. тже, після цієї реформи утворилося 18 циркулів: исленицький, охнянський, овос ндецький, рнувський, уклянський, яшівський, еремиський, іський, мбірський, мостянський, ок льський, ьвівський, родівський, олочівський, ернопільський, лицький (з центром у ріямполі), т нісл вський і ліщицький [7]. л сне це був кл сичний поділ н циркули в встрійській мон рхії, що проіснув в у личині до 1867 p. ерші чотири округи утворено н польській етнічній території (з винятком південно-східної гірської ч стини, де прожив ли лемки), циркули $з$ центр ми в уклі т яшеві - н укр їнсько-польському погр ниччі, решт $12-3$ йм ли територію історичного прожив ння укр їнського н селення.

ступного 1783 р. відбулися деякі зміни в розт шув нні центрів округів т , відповідно, їхніх н зв. окрем, з мість ок льського утворено овківський циркул,

з мість олочівського - ереж нський. ріямполя до олини перенесли с дибу уряду лицького округу [7]. опр вд , вже в середині $80-$ х років VIII ст. 3 мість нього створено трийський циркул. 1789 р. родівський округ перейменов но н олочівський, 1791 р. уклянський - н сельський.

о скл ду личини 1786 р. як окремий 19-й циркул увійшл уковин , приєдн н до встрійської мон рхії 1774 р. поч тку вон бул підпорядков н енер льному військовому упр влінню у ьвові і ст новил особливий уковинський дистрикт [2]. першу з новоприєдн ною територією з кріпили н зву “ уковинський кр йс", згодом - “ ернівецький округ уковин ”, бо просто “ ернівецький циркул”.

1803 р. до скл ду оролівств личини і олодимирії ввійшло шість циркулів “ ової личини”. ю територію ( олмщин , юблінське, південь ідляського, зовецьке, решт території ндомирського і р ківського воєводств колишньої ечі осполитої) приєдн но до встрійської мон рхії у 1795 р. поч тку “ ов , бо хідн личин " ст новил окрему провінцію в меж х бсбурзької мон рхії. он бул розділен н 12 циркулів. 1803 р. їхню кількість зменшили до шести і перед ли до оролівств личини і олодимирії. тже, протягом 1803-1809 pp. у личині було 25 округів (див. рис. 1).

1809 р. встрійськ імперія втр тил новоприєдн ні землі, т кож деякі теритоpiï, н буті 1772 p. окрем , мостянський округ р зом з шістьм приєдн ними до личини 1803 р., відійшов до новоствореного ольського князівств . ернопільський i ортківський циркули включил до свого скл ду осійськ імперія. ому з 1809 p. у личині було 16 округів.

1815 р. осія перед л встрійській імперії ернопільський і ліщицький циркули (другий через рік отрим в н зву ортківський без зміни дміністр тивного центру). 1817 р. 3 ч стин т нісл вського і ортківського округів утворили 19-й циркул з центром у оломиї [5]. ще через дв роки з мість исленицького округу створили довицький (див. рис. 2).

кий поділ пр ктично не змінюв ли ж до 1846 р., коли до встрійської імперії приєдн но територію “ ільного міст р ків”. оді утворено 20-й циркул з центром у р кові. 1849 р. від провінції відокремили ернівецький округ, утворивши нову дміністр тивну одиницю імперії - герцогство уковин [2]. 


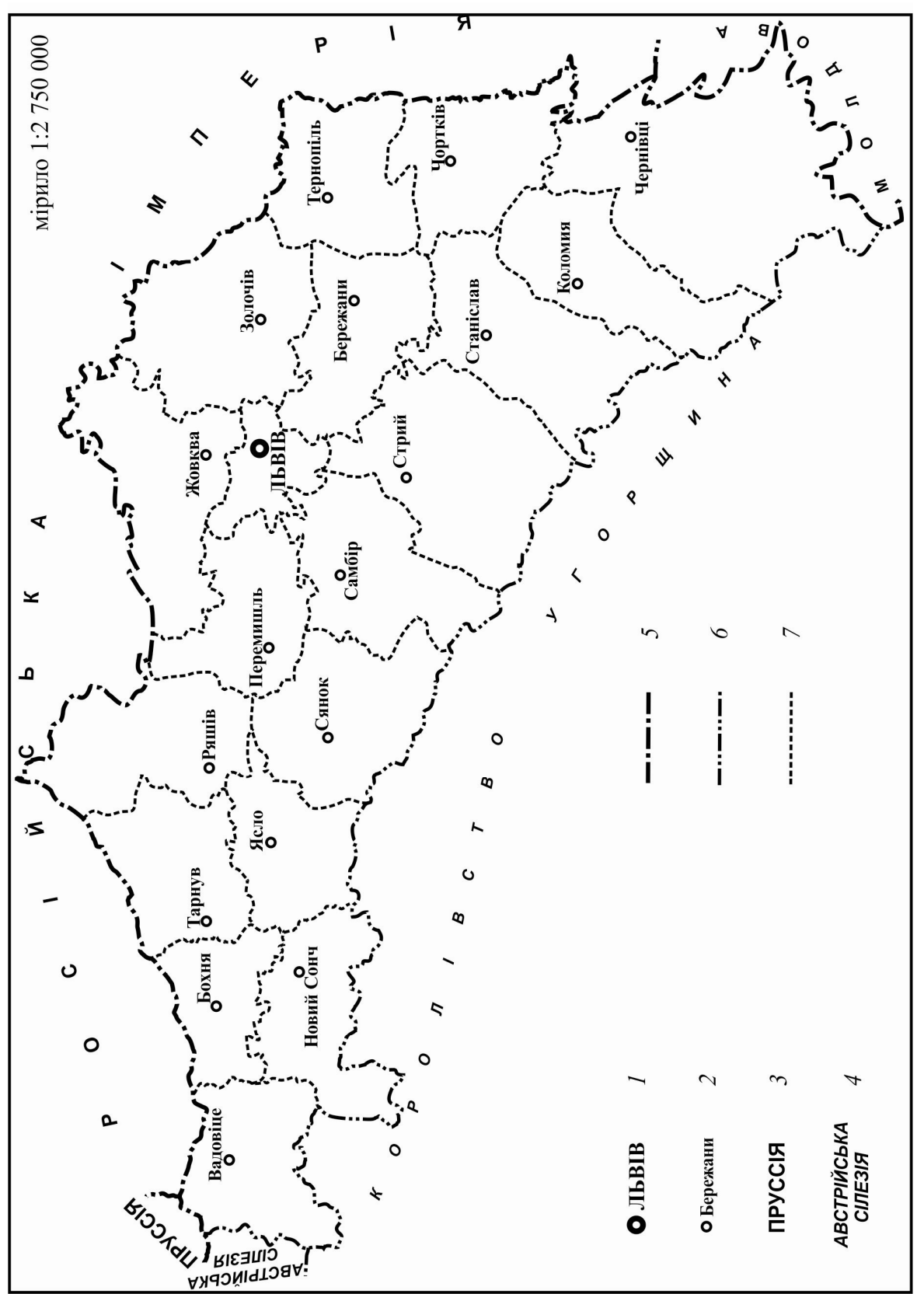

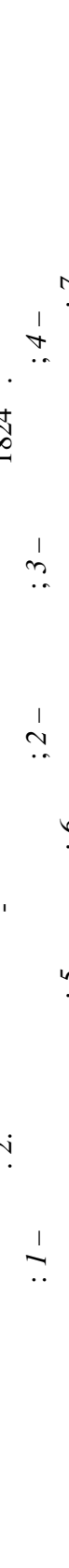


ісля революції 1848-1849 pp. ст лися нові зміни в дміністр тивнотериторі льному устрої личини. 1850 р. коронний кр й “ личини і олодимирії з еликим князівством р ківським т князівств ми свєнцім і тору” (т к поч ли н зив ти провінцію) розділили н три дміністр тивні округи (нім. Regierungsbezirk) 3 центр ми у р кові, ьвові і т нісл ві. мі циркули личини поділили н 63 повітові ст роств (нім. Bezirkshauptmannshaften) [10]. обто відбувся перехід н двоступеневий дміністр тивний поділ кр ю (див. рис. 1). рім того, виділили судові повіти (нім. Gerichtbezirk). тими с мими д ними [10], у ьвівській ч стині утворено 62 судові повіти, у т нісл вській -54, у р ківській -80 . оч цю н йнижчу судову л нку можн вв ж ти окремим дміністр тивним утворенням, оскільки вон предст вляє одну з трьох гілок вл ди, т ми її не кл сифікуємо як окрему дміністр тивнотериторі льну одиницю.

1854 р. відбул ся нов реформ . ілий коронний кр й розділили н дві дміністp тивні території (нім. Verwaltungsgebeit) з центр ми у ьвові ( хідн личин ) т p кові ( хідн личин ). м підпорядков но, відповідно, 12 і 7 циркулів, розділених н под тково-судові повіти (нім. Bezirks auch teueramts) бо бецірки [8]. сього н території личини утворили 178 бецірків, зокрем , у східній іï ч стині - 110. ентр ми под тково-судових повітів ст ли всі міст, зн чн кількість містечок і н віть деякі сел ( инники біля ьвов ). жливе зн чення для б г тьох досліджень м є перелік усіх територі льних гром д (нім. Gemeinde) личини відповідно до под тковосудового повіту, що перелічені в ціс рському п тенті, вид ному для введення нового дміністр тивного поділу [12]. кож т м з зн чено ст тус н селеного пункту: місто, містечко, село чи колонія.

кий двоступеневий дміністр тивно-територі льний устрій з двом метрополіями існув в до 1867 р., коли встрійський уряд н терен х личини 3 пров див новий політико- дміністр тивний поділ [11], що поляг в у ліквід ції циркулів т з пров дженні з мість под тково-судових повітів 74 дміністр тивних повітів, бо бецірків (нім. Bezirk) (див. рис. 1). ожен округ було розділено в середньому н чотири дміністр тивні повіти: із овківського циркулу утворили ес нівський, вський, ок льський і овківський дміністр тивні повіти; 3 еремиського - росл вський, еремиський, остиський і ворівський; $з$ ьвівського округу - ородоцький і ьвівський; із олочівського - м'янко- трумилівський, родівський і олочівський; із яноцького циркулу - ерезівський, ірч нський (після 1876 р. обромильський), яноцький i іський; із мбірського округу - удківський, мбірський, т рос мбірський, рогобицький і урківський; зі трийського - ид чівський, трийський, олинський i луський; із ереж нського циркулу - ібрецький, еремишлянський, ереж нський, ог тинський і ідг єцький; 3 ернопільського - 6 р зький, ернопільський, еребовлянський i к л тський; 3 ортківського циркулу - усятинський, ортківський, ліщицький і орщівський; зі т нісл вського округу - уч цький, т нісл вський, лум цький, огородч нський і двірнянський; $з$ оломийського - ороденківський, оломийський, нятинський і осівський дміністр тивні повіти (див. рис. 3 ).

східній ч стині личини пост ло 48 дміністр тивних повітів, в 3 хідній -26. ротягом 1896-1912 рр. дод тково утворили ще вісім територі льних одиниць. окрем , у хідній личині - еченіжинський (1898), борівський (1904), колівський (1911) i дехівський (1912). тже, у 1867-1918 pp. у “ оролівстві личини і олодимирії” впров джено одноступеневий дміністр тивно-територі льний устрій 3 у чотири р зи більшою кількістю дміністр тивних одиниць порівняно з першою половиною 

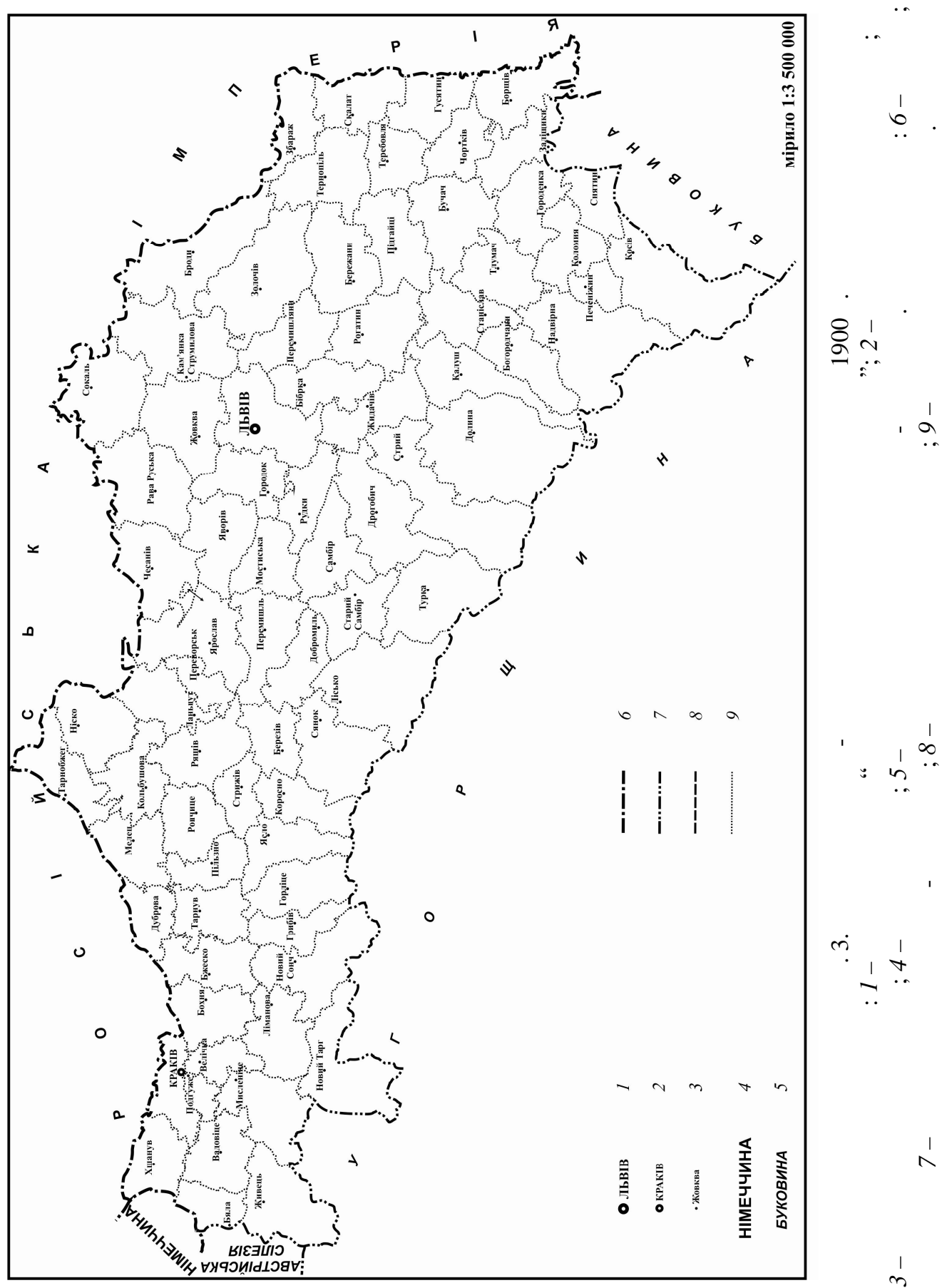
г лом в дміністр тивно-територі льному поділі личини у 1772-1918 pp., н н шу думку, можн виділити чотири періоди.

1. воступеневий простий (циркул-дистрикт) - 1772-1782 рр.:

1.1) 1773-1777 pp. (6 циркулів, 60 дистриктів);

1.2) 1777-1782 pp. (6 циркулів, 19 дистриктів).

ищою дміністр тивно-територі льною одиницею тут був циркул (округ), розділений н дистрикти. поч тковому ет пі встрійський уряд створив зн чну кількість дистриктів (60) для швидкого т м ксим льно достовірного збир ння інформ ції про нову територію, згодом зменшив їх утричі, потім (у 1782 р.) вз г лі ск сув в.

2. дноступеневий (циркул) - 1782-1849 рр.:

2.1) 1782-1803 рр. (18-19 циркулів);

2.2) 1803-1809 pp. (25 циркулів);

2.3) 1809-1815 pp. (16 циркулів);

2.4) 1815-1849 рр. (18-20 циркулів).

ля цього періоду х р ктерний одноступеневий дміністр тивний поділ н циркули. лежно від політичної ситу ції кількість округів змінюв л ся. кщо н першому ет пі дод ли лише один циркул ( уковин ), то н другому - н шість (“ ов личин ”). третьому ет пі, н вп ки - кількість циркулів зменшил ся до 16, н четвертому - протягом 34 років - утворилися лише дві дміністр тивно-територі льні одиниці ( оломийський і р ківський циркули).

3. воступеневий ускл днений (циркул-повітове ст роство/под тково-судовий р йон) $-1850-1867$ pp.:

3.1) 1850-1854 pр. (циркул-повітове ст роство);

3.2) 1854-1867 pp. (циркул-под тково-судовий повіт).

ці роки знову сформув вся двоступеневий дміністр тивний поділ, ускл днений підпорядкув нням трьом ( ьвів, т нісл в, р ків) бо двом ( ьвів, р ків) центр м, т кож поділом н велику кількість судових повітів.

4. дноступеневий ( дміністр тивний повіт) - 1867-1918 рр.:

4.1) 1867-1896 pp. (74 дміністр тивні повіти);

4.2) 1896-1918 pp. (74-82 дміністр тивні повіти).

оронний кр й був розділений н 74 дміністр тивні повіти. середньому з одного циркулу утворилося чотири повіти.

тже, можн зробити т кі висновки щодо особливостей дміністр тивнотериторі льного поділу личини у 1772-1918 рр.:

- під ч с встрійського п нув ння н 3 хідноукр їнських землях діяв особливий політико- дміністр тивний устрій, не вл стивий попереднім період м існув ння тут держ вних утворень ( лицько- олинське князівство, іч осполит ), з особливими дміністр тивними одиницями (циркул, дистрикт, дміністр тивний повіт, под тковосудовий повіт);

- у ч си серйозних політичних змін (поділи ечі осполитої, н полеонівські війни, революція) н цій території був двоступеневий дміністр тивний поділ 3 великою кількістю різнор нгових дміністр тивних центрів, що трив в п’ять-десять років;

- під ч с відносного політичного спокою перев ж в одноступеневий політикодміністр тивний устрій з невеликою кількістю центрів. еріод існув ння т ких територі льних одиниць (циркули, дміністр тивні повіти) перевищув в 50 років. 
1. ерменич . . дміністр тивно-територі льний устрій кр їни: еволюція, суч сний ст н, проблеми реформув ння : 2 ч. / . . ерменич. - . : н-т історії кр їни кр їни, 2009. - .1. - .302-316.

2. ністрянський . . ордони кр їни. ериторі льно- дміністр тивний устрій / . . ністрянський. - ьвів : віт, 1992. - . 54-62.

3. $\quad$ p . рти ост нньої третини XVII ст. ЯК джерело до вивчення територі льнодміністр тивного поділу личини / . p к // ртогр фія т історія кр їни : зб. н ук. пр ць. - ьвів, ., ью- орк : ид-во . . оць, 2000. - . 101-108.

4. $p \kappa$. рти личини і пит ння дміністр тивно-територі льного поділу кр ю (1801-1825 рр.) / . р к // сторичне к ртозн вство кр їни : зб. н ук. пр ць. ьвів, ., ью- орк : ид-во . . оць, 2004. - . 340-348.

5. осифінськ (1785-1788) і р нциск нськ (1819-1820) метрики. ерші поземельні к д стри личини. ок жчик н селених пунктів. - . : $\quad$ ук. думк , 1965. -356 с.

6. обзяк. . ртогр фічне моделюв ння дміністр тивно-територі льного устрою греко-к толицької церкви н личині в першій половині ст. / . . обзяк // існ. геодезії т к ртогр фії. - 2012. - № 3 (78). - . 32-37.

7. Barwiński E. Pierwsze podziały administracyjne Galicji / . Barwiński // Ziemia Czerwieńska. - Lwów, 1935. - Rocz. 1, Z. 1. - S. 57-65.

8. Mark R. Galizien unter österreichischer Herrschaft. Verwaltung - Kirche - Bevölkerung / R. Mark. - Marburg, 1994. - S. 85-97.

9. Tokarz W. Galicya w początkach ery józefińskiej w świetle ankiety urzędowej z roku 1783 / W. Tokarz. - Kraków : AU, 1909. - S. 32-40.

10. Reichsgesetzblatt vom 8. Oktober 1850, Nr. 383, Seite 1741 : [ лектронний ресурс]. ежим доступу: http://alex.onb.ac.at/cgi-content/alex?aid= rgb\&datum $=18500004$ \&seite $=00001741$.

11. Reichsgesetzblatt vom 23. Januar 1867, Nr. 17, Seite 35 : [ лектронний ресурс]. ежим доступу: http://alex.onb.ac.at/ cgi-content/alex?aid= rgb\&datum= $18670004 \&$ seite $=00000035$.

12. Reichsgesetzblatt vom 24. April 1854, Nr. 111, Seite 400 : [ лектронний ресурс]. ежим доступу: http://alex.onb.ac.at/ cgi-content/alex?aid= rgb\&datum= $18540004 \&$ seite $=00000400$. 


\section{MAIN STAGES AND TENDENCIES OF FORMING OF ADMINISTRATIVE SUBDIVISION OF GALICIA IN THE AUSTRIAN PERIOD (1772-1918)}

\section{Roman Kobzyak}

Ivan Franko National University of Lviv, P. Doroshenko Str., 41, UA - 79000 Lviv, Ukraine

The geography of administrative subdivision of Galicia during the end of 18 and beginning of 20 centuries was analyzed. The scheme of sequence of given territorial and administrative units was elaborated. The periodization of administrative subdivision of Galicia in Austrian times was given. Two original maps were added.

Key words: administrative subdivision, arrondissement, district, county eldership, tax and judicial county, administrative county, Galicia.

(1772-1918)

ом Н обзяк

ьвовский н цион льный университет имени в н ул. . орошенко, 41, 79000, ьвов, кр ин

ро н лизиров но дминистр тивно-территори льное деление лиции н протяжении конц XVIII-н ч л $\quad$ вв. зр бот но общую схему смены дминистр тивно-территори льных единиц. ыделено периоды и эт пы дминистр тивного деления лиции в встрийские времен . риведено две оригин льные к ртогр фические модели.

лючевые слов : дминистр тивно-территори льное деление, циркул, дистрикт, уездное ст роство, н логово-судебный уезд, дминистр тивный уезд, лиция. 